\title{
Transnational Advocacy Networks in International Supply Chains: A Study of Civil Society Organizations' Sugar Movements in Cambodia
}

\author{
Young Sokphea \\ The University of Melbourne, Australia \\ sophiabelieve@gmail.com
}

\begin{abstract}
As a contribution to the growing literature on transnational advocacy networks (TANs) in the global production networks, this paper examines how Civil Society Organizations (CSOs), which have adopted the framework of TANs, influence the sugar industry in Cambodia. Due to ineffective domestic influencing strategies, the CSOs adopted the TANs framework and escalated to the international supply chain movement approach (ISCMA) aiming to influence international stakeholders at each stage of the sugar supply chains in order to leverage boomerang pressure on the sugar producing companies, and the Government of Cambodia. Despite its resourceful networking strategies, ISCMA failed to leverage significant influence on the sugar companies and the Government to achieve their demands. The failure was not due to weak networks, but was in part due to the political nexus between the Government and the sugar companies. This paper suggests that to ensure the effectiveness of CSOs' actions within the TANs framework in the global production networks, one should take into account the power of the Government in relation to local politico-commercial elites.
\end{abstract}

\section{Keywords:}

Sugar, (social) movements, transnational advocacy networks, international supply chains, civil society organizations

\section{Introduction}

Originally influenced by new social movements and resource mobilization theories, transnational advocacy networks (TANs) of Keck and Sikkink (1998, 1999) has become increasingly popular amongst local and international advocacy or movement organizations in the global production networks in which products are produced and distributed globally. One of the most applicable notions of TANs is a 'boomerang pattern.' The domestic actors, including activists and NGOs whose resources are limited, seek out the international community who is able to spread their messages and concerns (Keck \& Sikkink, 1998, 1999). The international community employs various forms of influencing strategies to leverage pressure on the national Governments or institutions to address, not only the grievances of the domestic activists and NGOs, but also the grievances of the affected peasants and other grassroots communities. Theoretically, this is one among several approaches of TANs to campaign successfully; but in practice, different stakeholders involved at different stages of the production network always bear different interests and power. This is probably also true when it comes to complex stakeholders in the international supply chains of a particular product - from the producers to the end consumers, trade facilitators and donors. Power in this instance is located at multiple institutions of decision-making in different political contexts: national and international, State/Government and non-state (Macdonald, 2014). This has cast doubt on whether the boomerang actions of activists within TANs really 
influence these stakeholders to exert pressure on the nexus between national Government and companies in a complex political system like that of Cambodia.

To address the aforementioned doubt and as a contribution to the growing literature of TANs, this paper examines how and to what extent the Civil Society Organizations (CSOs) which have adopted the framework of TANs influence the foreign joint-venture companies and the Government of Cambodia to achieve their demands. To do so, the study draws on a case of CSO movements targeting the sugar companies and the Government in Cambodia. Due to the weak influence of domestic movement strategies, CSO activists staged international influencing strategies — the so-called international supply chains movement approach (ISCMA) - to seek pressure from international stakeholders at each stage of the sugar supply chains. ISCMA was adopted according to TANs in order to leverage boomerang pressure on the Government and the sugar companies in Cambodia. However, this transnational approach could influence the sugar companies and the Government to address only some, but not all, of the CSOs' demands. As a result, CSOs failed to achieve satisfactory results. The paper argues that the failure is not preliminarily explained by the international actions of CSOs within the TANs framework, but by the strong local political nexus between the Government and the sugar companies. This suggests that, seeking the more successful outcomes of CSOs in the TANs framework, scholars of TANs should take into account how the power relationship between Government and business responds to activists of TANs. The power relationship in terms of patron-client networks between the political elites and businessman is more powerful than the boomerang approach — international influencing strategies which tend to delegitimize the national Government's sovereignty.

This paper begins with a review of theoretical concepts of TANs that has shaped the notions of CSOs' international influencing strategies. In this review, the paper also conceptualizes the responses of Government and the companies. The paper then discusses the empirical findings pertaining to CSOs' ISCMA and its effectiveness with regard to TANs. Finally, the paper concludes and offers the implications of this case study for TANs studies.

\section{Transnational Advocacy Networks in the International Supply Chain Movement}

This section conceptualizes that civil society organizations (CSOs), including community based organizations (CBOs) and NGOs, which are known as movement actors or activists, have adopted the TANs framework to ensure their effectiveness in influencing the targets, including the Government and corporations, to address their demands/grievances.

\section{Transnational advocacy networks and civil society organizations}

CSOs play a significant role in influencing, not only the Government or State, but also businesses to ensure the interests of the public sphere (Hutter \& O'Mahony, 2004; McIntosh \& Thomas, 2002; Nugroho, 2011). To empower the marginalized grassroots communities, CSOs elevate the interests of the communities to the international arena to overcome domestic suppression and to leverage pressure from international communities. Through this boomerang process, CSOs have recently adopted the TANs framework. Influenced by new social movements (Dalton, Kuechler \& Burklin, 1990) and resource mobilization (Shawki, 2011; Smith, 2004), Keck and Sikkink (1998; 1999) constructed TANs as a framework of analysing transnational advoacy of transnational actors. TANs is believed to have a significant contribution to influencing strategies and effectiveness of transnational movements of CSOs in the global production networks.

Keck and Sikkink (1999) define TANs as those actors who work internationally on a particular issue and are bound together by shared values, a common discourse, and dense 
exchange of information and services. TANs' actors include, but are not limited to international and domestic NGOs, advocacy organizations, local social movements, foundations, media, trade unions, consumer organizations, and regional or international intergovernmental organizations, all of which are generally known as CSOs. These actors or activists employ leveraging political tactics and enrolling powerful actors to affect a situation where weaker members of a network are unlikely to influence the targets - either State or non-State actors. These are more likely to be effective due to density with many actors, strong connections among groups in the network, and reliable information flows (Keck \& Sikkink, 1998). TANs is often led by international and domestic NGOs that focus on international campaigns to influence Governments, international organizations, and the public at large. This can be established through networks of domestic partners (NGOs) in developing countries, and international partners who share similar interests (Keck \& Sikkink, 1998). Through this boomerang pattern, Jackie Smith (2004) endorses that, due to its membership network and density of information exchange, TANs leads to successful campaigns. However, it is costly and time consuming to mobilize and to coordinate a large number of actors across a region and in different places. In TANs, as those resource-rich (financial and technical resources) actors in the North often assist the resource-poor actors in the South, the North actors tend to gain more legitimacy and dominate the South actors (Meierotto, 2009; Jordan \& Van Tuijl, 2000) operating in a different political and cultural contexts. In so doing, the actions of these actors within the TANs framework might not be effective to leverage influence on the targets.

\section{Influencing strategies of CSOs and responses of the targets}

In TANs, the primary tactical influence is networking and information sharing. Recently, not only do CSOs adopt the tactics/concepts of TANs, but they are also shaped by the tactics of social movements. In social movements, scholars suggest two important tactics: (i) institutional actions (peaceful protest, petition, filing complaint, etc.); and (ii) noninstitutional actions (violent protest and any other harmful activities) (Sokphea, 2016; Cress \& Snow, 2000; Gamson, 1990; Giugni, 1998; McAdam, 1983; McAdam \& Tarrow, 2000). These tactics are more likely employed to target the State or the Government, rather than the private sector. To address this issue, McAdam and Tarrow (2000) postulate extra-institutional tactics, including boycotting, campaigning and defamation. These are used to target corporations that possess no institutional power that the Government does (King, 2008; King $\&$ Soule, 2007). Although extra-institutional tactics are similar to those non-institutional and institutional tactics, they tend to particularly target corporations or the private sector. Influenced by (extra) institutional tactics and networks of actors within TANs, this study investigates how CSOs' peaceful protests, petitions, networks, and complaints exert influence on stakeholders in the international supply chains of sugar products.

Scholars argue that the targets of social movements can be both the Government or the State, and corporations (Soule 2009, 2012), though most of the scholars claim that most of the movements primarily target the Government (Van Dyke, Soule \& Taylor, 2005). It is argued that previous social movements tended to target the Government/State, but in the era of increasing corporate power, the target of social movements has diverted to corporations (Soule, 2009). This study presents that at least one Government/State is an object of claim or a party to claim (McAdam, Tarrow \& Tilly, 2001). Soule (2009) argues that Government has stronger capability, not only to regulate corporations, but also to address the claims of hostile groups. This study places more emphasis on both private companies/corporations and the Government. Despite the clearer concepts of influencing strategies and the targets of TANs and social movements, there is a lack of clear definition of how the targets respond to CSOs' 
influencing strategies or tactics. One among several reasons of this shortcoming is the overwhelming emphasis on actors' actions and the dynamics of either TANs or social movements. To address the aforementioned shortcoming, the study draws on scholars of civil resistance who define similar mechanisms of response. Goldstone and Tilly (2001) and Cai (2010) posit four potential mechanisms of Government response. The first is concession, meaning that the demands of grassroots communities (or members of CSOs) are fully addressed. These grassroots movements then succeed in achieving their demands. The second is concession with discipline which is when the demands of the grassroots communities are addressed, but some or all protestors are punished (arrested or charged). This mode of response can also be overt in terms of limited concessions offered by the targets of the protests, and in the meantime, the targets repress the activists. The third mode of response is tolerance where the targets of the protests tend to ignore the protests, and take no actions against them. The fourth mode of response is known as repressive measure. This mode is defined as to when the demands of grassroots communities are ignored, and the targets punish some or all members of the communities (Cai, 2010; Goldstone \& Tilly, 2001).

Despite their four mechanisms of responses, Cai (2010) nor Goldstone and Tilly (2001) fail to define how a Government concedes when contention involves three actors: CSOs, corporations and the Government. The study endorses Soule's $(2009,2012)$ argument that, in the age of an increasing corporate power, the Government partakes as an intermediary and a regulator. The study defines a mechanism of Government concession as a process of regulating the corporations to address the desires of the challengers. By regulating, it means the process of enforcing relevant regulations to manage the corporations operating in a host country, to borrow from Ayres and Braithwaite's (1992) responsive regulatory enforcement. There are two options that the corporations have in response to the Government and the movement (King, 2008; Soule, 2009). In this contestation, once the Government concedes, the corporations have to comply with the Government's regulatory (re)enforcement to address the demands of the movement. If the Government does not concede, the corporations just ignore the demands of the movement. But, if the movement promptly targets both the Government and corporations, the corporations might accede by self-regulating or changing their policies to address the demands of the movement/ grassroots communities (Soule, 2009; King, 2008). With these mechanisms of response, the movement succeeds when it successfully influences the Government to regulate the corporation, and likewise, corporations concede by adjusting its policies or self-regulating to address the demands of the movement (Sokphea, 2016).

Although success or failure in achieving the demands or grievances of social movements remains contested (Steedly \& Foley, 1979), this study perceives that CSOs' ISCMA succeeds when their demands are fully addressed by the targets (the Government and the sugar companies); otherwise they fail. The study acknowledges that there are indirect impacts of the movements (e.g. capacity of activists), but these are out of the scope of the study.

\section{Cambodia's Political and Economic Contexts at a Glance}

After the collapse of the genocidal regime that slaughtered about two million Cambodians in 1979, Cambodia has transformed its politics and economy. Politically, Cambodia transitioned itself from communism to a democratic regime in 1993 when the first election was organized by the United Nations. Since then, although the country has gone through five rounds of national elections, democratization in Cambodia is still incomplete. Despite being known as electoral authoritarianism, neo-authoritarianism, hybrid or new democracy (Baaz \& Lilja, 2014; Heder, 1995; Un, 2011, 2013), Cambodia is also known to a number of scholars as a neo-patrimonial regime (Hughes, 2003; Un, 2011; Un \& So, 2011). Corroborating with the 
later scholars, the study asserts that Cambodia is inevitable a neo-patrimonial regime, with Hun Sen serving as Prime Minister, a central power holder, for more than three decades. The tenure of Hun Sen has been made possible because of his winning coalition's patronage system (Un, 2013). In this system, patron-client networks are entrenched from the central level to the local level (village), and in various practical aspects, such as the appointment of a person to a lucrative position (rent seeking) and resource allocation (Hughes, 2003).

Economically, Cambodia has transformed itself from a centrally planned economy to a free market economy, and so has striven to integrate itself into regional and international communities. Cambodia has, since then, invested efforts to attract foreign investments, aside from foreign aid, to develop its economy. In particular, foreign investments have been increasing since the late 2000s. Though it declined dramatically from US $\$ 10,891$ million in 2008 to US\$5,611 million in 2009 due to the global economic crisis, the investments in the agricultural sector have rapidly increased from US\$27 million in 2005 to US\$446 million in 2009 (CDC, 2010). This was due to the Government's issuance of a Sub-decree on Economic Land Concessions (ELCs) to attract foreign investors in 2005 (RGC, 2005). Not only has the Sub-decree attracted investors, it was also aimed at generating economic growth, employment and reducing poverty in rural communities. Through the ELCs, foreign investors are granted land concession licenses for up to 99 years. As of late 2012, at least 2.6 million hectares of land have been granted to private companies (both foreign joint ventures and domestic investors) (ADHOC, 2013). In contrast to the sub-decree objectives, the development practitioners, activists, NGOs, pundits and scholars have accused that these, but not all, foreign investments are the sources of deteriorating social, economic and environmental conditions of local communities (Un \& So, 2011; Milne \& Mahanty, 2015). Among several reasons, these adverse impacts are induced by the ambiguous regulatory enforcements (especially the ELCs Sub-decree, EIA Sub-decree and Land Law 2001), and the lack of corporate responsibility of the companies that are granted ELCs. Since the early 2000s, about 770,000 people in several provinces have accumulatively been affected by ELCs (ADHOC, 2014).

Despite such obvious harmful impacts, those foreign and domestic investments are secure because they are joint ventures with the local powerful tycoons and senior officials (Un, 2009). These local elites have protected the foreign investors. Although they learnt the symbiotic relationship between the investors and local elites, the affected communities, which have organized themselves as CBOs, and with the support of NGOs, have challenged both the Government and the foreign joint venture companies to address their grievances. Some of the affected CBOs have employed several tactics, including violent and non-violent protests, petitions with several local and international institutions, lobbying the Government and companies, and networking with local and international NGOs. These movement tactics - more often than not - have encountered repressive responses by the Government or the companies. These repressive responses include harassment, arrests, violent dispersals of the peaceful protests and imprisonment of the ringleaders by using the judicial system (NGO Forum, 2011). In 2012, because of rampant protests by the CBOs and NGOs, the Prime Minister issued a concessive Directive No. 01BB on the moratorium of ELCs. Not only did the Directive aim to postpone allocating additional ELCs to companies, it also ordered all companies that were involved in conflicts with the communities to return land to the affected families (RGC, 2012). A number of the CBOs were reported to have benefited from the Subdecree, but others did not.

Because of the aforementioned responses by the Government and the companies, which were a combination of repression and concession, the CBOs and NGOs experienced a mixture of outcomes - either success or failure in achieving their demands (see Touch \& 
Neef, 2015; Schoenberger, 2015; Alder et al., 2006). However, there have not been many studies conducted to explain the dynamics of these movements and their achievements.

\section{Research Methods}

With a limited budget and time, this study drew on a case of the transnational movement of CSOs targeting the sugar industry and the Government to explain the dynamics of their movements, and to examine what explains their success or failure to achieve their demands within the framework of TANs. The study has adopted a case study approach, which involves the investigation of a particular aspect of a past episodic event to develop or test historical explanation that may be generalizable to other events (George \& Bennett, 2005). However, the study did not attempt to test theory, but to explain why transnational activists of CSOs within the TANs framework failed to achieve their demands. Among other cases, transnational movements of the community against the agro-sugar industry in Koh Kong province were chosen because of two reasons. First, the durability of movements of the communities becomes a model case of grievance redress in Cambodia. Second, it is the first case that adopted the framework of TANs to influence both the Government and agroindustrial companies in Cambodia. Lessons learnt from this case have been drawn by a number of NGOs to leverage influence on other cases which have emerged in the agroindustrial sector.

In addition to a review of literature and relevant documents, the study conducted semistructured interviews with twenty-two key informants (see Appendix 1) and two interactive focus group discussions to collect empirical data. These correspondents represented all stakeholders involved in the dispute (companies, Government, NGOs and community). Informants were three community activists, four NGO staff, nine local and senior Government officials (including ELC secretariat), two company staff, and two academic and independent researchers. Ten villagers from a diverse background were invited to participate in each interactive group discussion. The study employed the snowball approach to select informants from NGOs, Government officials and other experts. All interviews were audiorecorded and the names of respondents were anonymised to comply with research ethics. The fieldwork was conducted between August 2013 and January 2014. Based on the interviews, the study employed qualitative data analysis using NVivo to store the interview scripts and used Query tool search for relevant terms and themes for analysis.

\section{International Supply Chain Movement Targeting An Agro-Sugar Industry}

This section empirically argues that, due to ineffective domestic influencing strategies and repressive measures of the Government, CSOs adopted the TANs framework, known as international supply chain movement approach (ISCMA), to leverage influence on the sugar companies and the Government. Although ISCMA of CSOs within TANs exerted certain influence on the sugar companies and the Government to address particular demands, empirical evidence proves that the CSOs failed to achieve all demands.

\section{Demands of CBOs}

In 2006, the Government granted 90-year ELCs to two foreign joint-venture companies, 
namely Company $\mathrm{A}^{1}$ (about 9,000 hectares) and Company B (about 10,000 hectares) in Koh Kong province. These companies are owned by a Cambodian Senator (senior politician of the ruling party), and Thai and Taiwanese investors. These ELCs were granted for planting sugarcane and constructing a sugar-processing factory. From 2006 to 2012, the Senator owned about twenty percent of the shares, fifty percent belonged to a Thai company, and the rest belonged to a Taiwanese company. Recently, the Senator is believed to have sold his shares to the Thai company (Pellechi, 2012), while the remaining shares still belong to the Taiwanese one. However, activists and local NGOs argue that the Senator remains influential within these joint-venture companies ${ }^{2}$ (the sugar companies hereafter) because the Senator frequently shows up to mediate the conflict with the affected communities and NGOs. The affected communities, which have formed themselves as CBOs to represent the affected families, claim that, although the Senator appeared to sell out his shares, he remains a target of their movements and NGOs. Activists claim that the Senator was the one who caused lingering adverse impacts on their members. ${ }^{3}$

Operating this large-scale sugarcane investment has caused adverse changes in the socioeconomic and environmental aspects of all four communities, where about 3,673 people (2,032 females) within 751 families reside. ${ }^{4}$ In May 2006, the sugar companies, accompanied by armed forces, bulldozed farmland, plantations, paddy fields, and forestland. The CBOs and NGOs have since then organized movements against the sugar companies and the Government. Based on group discussions, the CBOs demand ${ }^{5}$

i) to address the issue of breaching human rights as the sugar companies violated land and economic rights (right to proper occupation, income, and shelter) of the CBOs, and employed child labor,

ii) to return their land because the sugar companies illegally confiscated about 5,000 hectares of land previously belonging to 456 families,

iii) to fairly compensate the affected families either in cash or land swap if the land cannot be returned,

iv) to mitigate social issues, such as child labor in the sugarcane plantations, and the dropout rate among children, which is caused by the land confiscation by the sugar companies,

v) to stop kidnapping animals for ransom, and shooting cattle entering the sugarcane farms,

vi) to mitigate surface water contamination by the sugar companies whose discharged wastewater has caused fish death and health problems, and

vii) to comply with related regulations including the ELCs Sub-degree (2005), Environmental Impact Assessment (EIA) Sub-decree (1999), and Land Law (2001), which ensure sustainable development practices.

The CBOs and NGOs launched two phases of influencing strategies. The first phase was domestic influencing strategies orchestrated from 2006 to early $2010 .{ }^{6}$ Since, the domestic influencing failed to produce satisfactory results, CSOs staged the second phase, which was

\footnotetext{
${ }^{1}$ Names of these companies are pseudonym. This is to comply with research ethics and to ensure anonymity which is necessary for participants participating in this sensitive research topics.

${ }^{2} \mathrm{P} 02$ (please refer to the appendix)

3 P04, P10 and P12

${ }^{4}$ FDG1, FDG2, P04, P10 and P12

${ }^{5}$ FDG1 and FGD2

${ }^{6}$ This paper did not cover the dynamics of domestic influencing strategies.
} 
international influencing strategies, known as international supply chains movement approach (ISCMA), commissioned since $2010 .^{7}$

\section{International supply chains movement approach}

To achieve their demands, the CBOs initially employed peaceful protests and petitions, and filed complaints to seek support from Governmental institutions. However, the CBOs claimed that, as an initial response, the Government violently dispersed peaceful protests of the CBOs in September 2006. ${ }^{8}$ After the violent crackdown, the Government, in collaboration with the sugar companies, offered unfair cash compensation. The cash compensation was too cheap (US\$50-100 per household regardless of the size of land lost) to purchase another plot of land. ${ }^{9}$ Some affected families were either threatened or lobbied by the Government to accept the cheap cash compensation. To leverage influence and to alleviate repressive measures, the CBOs and NGOs adopted TANs framework, employing tactical escalation from domestic strategies to ISCMA.

Tactical escalation typically involves dramatic or innovative instruments and provocation that tests the vulnerabilities of one's foe (O'Brien and Li, 2006). Likewise, the CBOs and NGOs initiated and staged ISCMA to leverage pressure directly on the sugar companies, and indirectly on the Government. ISCMA introduced by local and international NGOs which adopted the notions of transnational networks of Keck and Sikkink's (1999) TANs. In ISCMA, with resourceful support of and information provided by local NGOs, the CBOs play an important role in leveraging boomerang pressure at each stage of international supply chains. The CBOs target and trace international stakeholders in the global production networks, from supplying, manufacturing and distributing to trade facilitators.

As part of TANs' information sharing, in 2010, local NGOs found out that raw sugar was exported from Cambodia to Thailand for final refinery by Khon Kaen Sugar Industry (KSL). The sugar was then exported to the United Kingdom (UK) through the European Union's (EU) Everything But Arms (EBA) ${ }^{10}$ scheme (Cock, 2011), and sold to Tate and Lyle (T\&L) in the UK. Given this information, CBOs - assisted by the local and international NGOs filed a complaint to the National Human Rights Commission of Thailand (NHRC-T) to seek boomerang pressure. Promptly, the NGOs, on behalf of the CBOs, wrote letters to T\&L. This boomerang approach of TANs aimed at exerting influence directly on the sugar suppliers in Cambodia to address the adverse impacts.

To exert stronger pressure, in May 2012, 200 affected families of the CBOs, facilitated by NGOs, filed a complaint against T\&L with a court in the UK. The complaint had been assisted by Jones Day, ${ }^{11}$ and a Cambodian lawyer (Peter \& Naren, 2013). The purpose of the complaint was to demand T\&L and its suppliers to address the demands of the CBOs. According to an interview, the court failed to try the case after several attempts in October 2014, and in early 2015. ${ }^{12}$ In the meantime, the CBOs filed a complaint to the EU in Cambodia and Brussels to intervene pertaining to the adverse impacts of the EBA program on marginalized communities. The CBOs and NGOs reckoned this as a significant step to

\footnotetext{
${ }^{7}$ It is more likely to endure, but the paper observes activities up to early 2015 only.

8 FDG1.

${ }^{9}$ FDG2.

${ }^{10}$ Founded 2001, it provides Least Developing Countries full duty free and quota-free to export all products except armaments to EU countries. Currently, 49 countries, including Cambodia, are beneficiaries of this scheme. See http://trade.ec.europa.eu/doclib/docs/2013/april/tradoc_150983.pdf\%3E (accessed 15 May 2015).

${ }^{11}$ Jones Day is a pro bono law organization that provides free of charge service to marginalized grassroots communities.

${ }^{12} \mathrm{P} 02$
} 
leverage boomerang pressure from the international community of stakeholders on the sugar producer companies in Cambodia. However, this approach within the TANs framework appeared to receive no fruitful responses.

\section{Responses of key stakeholders in the sugar supply chains}

The responses of key stakeholders to ISCMA of CSOs within TANs varied considerably, offering no satisfactory results besides giving excuses. In 2010, NHRC-T confirmed that KSL's subsidiary company infringed on the communities' rights. KSL initially claimed that its Cambodian partner (the Senator) had already remedied the impacts, but it inclined to provide cash compensation to address the remaining grievances. If CBOs wanted the land back, the company is happy to return, but only when the Government compensates the company with another plot of land. This signified the least influence of NHRC-T on KSL. ${ }^{13}$

From the buyer side, T\&L claimed no responsibility for the allegations. Nevertheless, Bunsucro $^{14}$ terminated T\&L from its membership in $2012^{15}$ because it did not address the adverse impacts following the complaints of CBOs and NGOs. Following the termination, T\&L sold its sugar business to American Sugar Refinery (ASR). This created a complicated issue in the supply chains of transnational movements of the CBOs and NGOs. To trace supply chains, the CBOs and NGOs, in collaboration with Earth Rights International in the U.S, wrote letters to ASR, but there was no response. Meanwhile, another complaint was also filed to OECD regarding the misconduct of ASR and their sugar suppliers in Cambodia. ASR responded by advising the communities and NGOs not to file two separated complaints (to the UK court and OECD) - they otherwise would not participate in the case ${ }^{16}$.

Although T\&L claimed that it sold the sugar business to ASR, the CBOs still complained against them as they used to extract a huge benefit at the expense of the communities. Following the lawsuit in mid-2013, T\&L negotiated with the CBOs in London. T\&L still denied the allegations, and claimed the positive impacts of its former suppliers' corporate social activities, such as the construction of schools, roads and hospitals. ${ }^{17}$ With confidence in the UK court, the remaining family members of CBOs did not accept any cash compensation, even though the sugar companies in Cambodia increased the offer.

Although international aid plays an important role in the development of Cambodia, the extent to which aid influences the Government in general remains controversial. Likewise, seeking intervention from a big donor and trade facilitator, namely EU (by far the largest bilateral donor in Cambodia), to influence the Government and the sugar companies is not a conducive manner. In 2011, a Member of Parliament (MP) from the EU visited the CBOs in Kampong Speu and Kong Kong provinces. The MP promised to bring the issue to the EU Parliament to conduct further detailed studies. Cambodia would be temporarily withdrawn from the beneficiary of EBA if serious and systematic violations of human and labor rights and the environment were revealed (Miller, 2011). In January 2014, the EU Parliament passed a resolution calling upon the bloc's executive body to urgently act on a EU preferential trade scheme found to have carried high risks of human rights violations in Cambodia. Following the resolution, another MP of EU officially visited Cambodia and

\footnotetext{
${ }^{13} \mathrm{P} 02$ and P06.

${ }^{14}$ Based in UK, the association provides certificate to member companies to prove that their sugars are bought with no link to human rights abuse or adverse impacts. T\&L is a member of this association.

${ }^{15} \mathrm{P} 06$.

16 According to its procedure, OECD might take further action until all parties agree to continue the case. Because ASR declined to continue with OECD, the case was finally dropped.

${ }^{17} \mathrm{P} 04$
} 
confirmed the serious impacts as claimed by the CBOs and NGOs. The EU would suspend or end the EBA scheme in Cambodia if no acceptable solutions were offered to the communities.

\section{Government responses to ISCMA within TANs}

In line with the defined theoretical concepts of Cai (2010), and Goldstone and Tilly (2001), the Government chose a combination of more repressive than concessive measures in response to the ISCMA of CSOs. This demonstrated that ISCMA within the TANs framework could not get rid of the repressive measures of the national Government as claimed by scholars (Keck \& Sikkink, 1998, 1999). The Government still possesses strong power although CSOs undertake TANs' boomerang actions.

As part of its repressive strategies, the Government suppressed and intimidated local NGOs that have since 2007 empowered the CBOs, in terms of capacity, legal support and advocacy strategies, to advocate the Government and the sugar companies.18 As elsewhere, the provincial governor in particular accused the local NGOs of acting as activists of an opposition party and of instigating the CBOs movements against the Government. ${ }^{19} \mathrm{~A}$ leading NGO was also warned by the Ministry of Interior to shut down its office as the Ministry accused them of working beyond its bylaw registered at the Ministry. ${ }^{20}$ The NGO was accused of being involved in political movements rather than being neutral and independent. These are quite common in Cambodia to allege, what most senior Government officials claim, Western interference in Cambodia's internal political affairs. The provincial governor accused NGOs, which assisted CBOs to stage international action with TANs, of receive funding from the Western Governments or donors to interfere with the internal political affairs of Cambodia. These NGOs helped and incited the CBOs to overthrow the legitimate Government (based on elections). ${ }^{21}$ This manifests the weakness of ISCMA with TANs' framework leading to the loss of identities of CBOs as they are shaped by the local and international NGOs' notion of TANs. Although a Western donor like the EU warned of terminating EBA in Cambodia, the Government appeared not to take effective actions. One among several reasons of this ignorance is increasing and unconditional aid and loans from China, a rising donor to Southeast Asia, including Cambodia; China is also a good trade partner of Cambodia (Burgos \& Ear 2010). Given its less restrictive regulations for imported products, the sugar companies once claimed that, if the EBA scheme in Cambodia was terminated, the executive officer of the sugar company claimed that they would consider diverting export to China where demands for sugar is strong. ${ }^{22}$

In addition to the above repressive measures, the Government resisted and accused the remaining families, who did not accept the cash compensation and persisted protesting and advocating, of being pro-opposition, though they claimed to be apolitical. ${ }^{23}$ Another reason for which the accusation was bolstered was because, during the 2013 election, the main opposition party set its agenda and promised to return all land to villagers from land speculators, and improper large-scale land acquisition. To some extent, protests and complaints by the CBOs were intangibly trapped and jeopardized in an opposition party's agenda. An activist argued that "Now, we cannot hold protests anymore, we would otherwise

\footnotetext{
${ }^{18} \mathrm{P} 02, \mathrm{P} 06$ and P22.

${ }^{19} \mathrm{P} 05$.

${ }^{20} \mathrm{P} 02$ and P19.

21 P05.

22 P13.

${ }^{23} \mathrm{P} 05$.
} 
step on the footprints of the opposition party, and that would result in severe repression and charges." 24

In 2012, the Directive No. 01BB of the Government was not enforced in the sugarcane plantation areas, and the CBOs were not reallocated while a number of communities affected by similar issues in Cambodia were reallocated land. Instead doing so, what the Government could do was negotiating with the sugar companies to offer partial concession. These partial concessions consist of cash compensation, and mitigating some social and environmental concerns. These offers did not address all demands of the CSOs.

\section{The responses of the sugar companies: cash compensation, mitigations, and change in corporate behavior}

In the wake of the increasing power of corporations, one among several objectives of movements is to influence Government in the hopes of it regulating corporations (Soule, 2009, 2012). Despite the aim of ISCMA of CSOs to directly influence the sugar companies, the host Government remains crucial whether or not to regulate the companies within their judicial areas. In so doing, ISCMA of CSOs, though sophisticated under TANs, was ineffective due to complicated and ambiguous roles and responsibilities of international stakeholders. Similar to the responsive strategies adopted before launching the ISCMA, what the Government could provide was only partial concessions (see above).

To comply with the partial concessions, the sugar companies, first, increased cash compensation (see Figure 01). According to an interview, this was offered to lobby the family members of CBOs to cease protests and complaints. ${ }^{25}$ In late 2012 , twenty-one families of CBOs accepted this cash compensation, and withdrew their participation from the movements. As of late 2013, the cash compensation was increased to around US\$3,500.0 per family, but none of the remaining members accepted the offer as they were confident in the UK court. ${ }^{26}$ Second, the sugar companies and concerned provincial departments mitigated water contamination by digging new ponds to store and treat the polluted water before discharging. Third, the sugar companies eliminated child labor in the sugarcane farms to address the CSOs' demands. Last, the sugar companies self-regulated by establishing a corporate social responsibility department, assisting community development activities, such as school maintenance and construction, rehabilitation of roads and other activities. ${ }^{27}$ Hence, the behavior of the sugar companies was shaped as claimed by Soule (2009) and King (2008). This self-regulation, which is not required by the law, aims to harmonize their investment operations with the CBOs. Although this suggests the indirect impacts of TANs on the behavior of the sugar companies in Cambodia, this adjustment did not address the demands of the CSOs.

\section{Discussion: The effectiveness of ISCMA within TANs}

The above empirical findings suggest that ISCMA of CSOs adopted the TANs framework to influence international stakeholders at each stage of sugar supply chain to influence the local producers and the Government. These CSOs employed information and leverage politics of TANs (Keck \& Sikkink, 1998, 1999). Trained by NGOs with a strong connection with the TANs, representatives/activists of $\mathrm{CBOs}$ played significant roles in the international

\footnotetext{
${ }^{24} \mathrm{P} 01$.

${ }^{25} \mathrm{P} 04, \mathrm{P} 10$ and $\mathrm{P} 12$.

${ }^{26} \mathrm{P} 04, \mathrm{P} 10$ and P12.

27 P05, P13 and P14.
} 
campaign, filing complaints and petitions to the country of origin of investment (Thailand, Taiwan) and buyers in the UK and the U.S and trade facilitator (EU's EBA) in each stage of the supply chain. Without participation of $\mathrm{CBO}$ activists and resourceful support from local and international NGOs, ISCMA of CSOs under TANs would be impossible. Local and international NGOs, in essence, gathered information and shared with the CBO activists to stage the boomerang influence on the sugar producers and the Government in Cambodia. In the meantime, NGOs used the strategy of leverage politics of TANs as an approach to assist the weaker groups - CBO activists in particular - to leverage influence in an attempt to achieve their demands.

To understand the effectiveness of CSOs within TANs, it is necessary to compare the initial demands versus the actual responses of the Government and the sugar companies. As above evidence suggests, ISCMA of CSOs within the TANs, to a certain degree influences the sugar companies and the Government to address some of their demands: cash compensation, partially mitigating livelihood issues, mitigating water contamination, and eliminating child labor. A remarkable achievement was an increased amount of cash compensation, from US\$2,000.0 in 2009 to 2,350.0 in 2010, and to about US\$3,500.0 in 2013 (Figure 01). Despite this significant achievement, ISCMA of CSOs has failed to influence the Government and the sugar companies to address all demands.

\section{$<<<$ Figure $1>>>$}

Source: Representatives of CBOs, and Sugar Companies' Reports $2012^{28}$

To compare the initial demands of CSOs and the actual responses, the sugar companies and the Government addressed only three out of the seven demands of CSO within TANs. Other demands, such as water quality, compliance with related regulations, returning land and/or offering fair cash compensation, kidnaping cattle and animals, and human rights violations (right to occupation, right to shelter) were not addressed. The remaining demands were not addressed because the Government and the sugar companies considered cash compensation and jobs as compensation to livelihoods and human rights. ${ }^{29}$ This is a common response of the Government of this neo-patrimonial political system where the political nexus between the Government and the sugar companies is strongly tied together to pursue economic benefits and political interests at the expense of the CBOs' common resources (Sokphea, forthcoming). Interviews acknowledged the failure by saying that "it is like hitting eggs against stone. ${ }^{, 30}$ However, they recognized the benefits of this movement, especially capacity, rights and legal awareness of the CBOs. ${ }^{31}$

As discussed in the economic and political context section, the symbiotic relationship between individuals of the ruling party (Cambodian People's Party of Hun Sen), and of the Government officials and businesspersons is apparently established in terms of patron-client networks (Hughes, 2003; Un \& So 2011). Those who possess more power or wealth tend to act as the middle patrons or clients of the central patron, Hun Sen, while those who possess less power tend to be clients. These patron-client networks form reciprocal, though not equal, benefit sharing (Scott, 1972). The patrons tend to protect the clients for political support and economic benefits, and the clients are inclined to seek protection from the patrons. In the recent decades, not only do these patron-client networks form with the public and

\footnotetext{
${ }^{28}$ It was paid per family, regardless of land size lost. No cash compensation was observed in 2011.

${ }^{29}$ FDG1

${ }^{30} \mathrm{P} 04$ and $\mathrm{P} 10$

${ }^{31} \mathrm{P} 19$
} 
Government administration, they are also established between the powerful Government officials and foreign investors (Sokphea, forthcoming).

The foreign investors sought joint venture with senators whose power and business activities dominate, not only Koh Kong province, but also other regions of the country. The senator was also known as the king of Koh Kong business who monopolized several investments, such as casino, hotels and other tourism investments. In this agro-sugar industry, the Thai and Taiwanese investors followed the first pathway. They had to collaborate with a powerful senator and close friend of the PM to facilitate all kinds of processes to get ELCs granted within a short period. ${ }^{32}$ A senior Government official unveiled,

They, the foreign investors, do not know the entry point for investment in Cambodia, such as where to go and to process the legal documents. So, the Cambodian partner has to process the documents for them, and they give $10 \%$ of the shares, to speak frankly... ${ }^{33}$

Documents requesting for ELCs that the study received suggest that these ELCs took only three months to obtain from the Council of Ministers (CoM) - much faster than for most companies. With this power, the sugar companies did not conduct proper public consultations or social and environmental impacts assessments, as required by the sub-decrees of ELCs (2005) and EIA (1999), and Land Law (2001) before approval by the CoM. As recorded in the demands of the CBOs, this concession is accused of violating these regulations. As stated in the Land Law, no concession is granted to a private company of greater than 10,000 hectares. This agro-sugar industrial investment was, however, awarded up to 19,100 hectares as it claimed to be two companies, but was operating as a single company. ${ }^{34}$ It was possible because of the power of the Senator, a major shareholder of the sugar companies. The power of the senator, as in 2012, protected the sugar companies from the enforcement of Directive No. $01 \mathrm{BB}$, ordering all companies involved with land grabbing to reallocate land to the communities. Having the Senator as a backup, ISCMA of CSOs within the TANs framework against the sugar companies are quite challenging. The Senator, as a middle patron, tended to protect the sugar companies - the clients.

In essence, the power of the intermediary (the Government) remains important although ISCMA of CSOs within TANs turned to target international stakeholders in each state of supply chain. Conceding or not depends on the Government who possesses stronger power in controlling and regulating corporations within their jurisdiction than the boomerang approach and the international stakeholders' roles. In this neo-patrimonial context, the political nexus between the Government and owners of the sugar companies undermines international activities of CSOs within TANs. These local political ties between the foreign companies and powerful individuals of the host Government in the context of global production networks appear to be neglected by King (2008) and King and Soule (2007), and especially by the actors of TANs of Keck and Sikkink (1998).

\section{Conclusion}

This paper discussed the interactions among CSOs, the Government and the sugar companies in Cambodia within TANs framework. Due to ineffective domestic influencing strategies and strong repression by the Government, the movements of CSOs (consisting of CBOs and

\footnotetext{
${ }^{32}$ On 17 March 2016, the sugar companies requested for land concession from MAFF and got approved by CoM on 29 June 2006.

${ }^{33} \mathrm{P} 05$.

${ }^{34} \mathrm{P} 06$.
} 
NGOs in the Cambodia context) resorted to the international supply chains movement approach (ISCMA), as international boomerang networks, to advocate international stakeholders to leverage pressure on the sugar companies and the Government of Cambodia.

Situated within a framework of TANs of Keck and Sikkink $(1998,1999)$, the CSOs' ISCMA targeted stakeholders at each stage of international supply chains, including the investors' country of origin (Thailand, Taiwan), the buyer companies in the UK, the UK court and the EU, to leverage pressure on the sugar producers and the Government in Cambodia. Evidence suggests that CSOs' ISCMA with TANs leveraged stronger pressure directly on the sugar companies, and indirectly on the Government, compared to the domestic influencing strategies. However, ISCMA yielded no satisfactory results (cash compensation, changes in corporate behavior and mitigating of some adverse social and environmental impacts). As not all of the CSOs' demands were addressed, they eventually failed to achieve all demands. Failure to do so was because of two important factors: (i) strong local political ties between the sugar companies and the Government in this neo-patrimonial political system, and (ii) complex and ambiguous roles of international stakeholders and trade facilitators/donors at each stage of the supply chains. The first appears to be decisive while the latter complements why CSOs failed to achieve all of their demands. In the neopatrimonial system, patron-client relations between the ruling party and individual business owners are commonly established. The patrons, including the rulers of the Government administration, tend to protect the clients, the owners of the sugar companies, for mutual and reciprocal support. These patron-client networks have been generally observed in Southeast Asia according to Scott (1972). In essence, although CSOs have adopted the TANs framework, which is believed to be effective boomerang movement networks, they are undermined by entrenched political networks.

These empirical findings suggest that actions of CSOs, especially ISCMA within the boomerang approach of TANs, are not necessarily effective in this context. To ensure the effectiveness of CSOs' actions within TANs, one has to consider not only the local political contexts, particularly when the Government and the companies are politically tied together, but also the ambiguous roles and power of international communities and stakeholders in the supply chains. These should not be taken for granted when studying of the effectiveness of CSOs' actions within the framework of TANs of Keck and Sikkink $(1998,1999)$ in the context of global production networks.

\section{References}

ADHOC (Cambodian Human Rights and Development Association). (2013) A Turning Point? Land, Housing and Natural Resource Rights in Cambodia, Phnom Penh, Cambodia: ADHOC.

ADHOC. (2014) Land Situation in Cambodia 2013, Phnom Penh: ADHOC.

Adler, D., Chhim, K., Heang, P., Hak, S., Sou, K. and Heng, K. (2006). Justice for the Poor? An Exploratory Study of Collective Grievances Over Land and Local Governance in Cambodia. Phnom Penh: World Bank and Centre for Advanced Study.

Cock, A. (2011) 'The Rise of Provincial Business in Cambodia', in C. Hughes, and K. Un (eds), Cambodia's Economic Transformation, Denmark: Nordic Institute of Asian Studies, 27-49

Ayres, I. and Braithwaite, J. (1992) Responsive regulation: Transcending the deregulation debate, Cambridge: Oxford University Press.

Baaz, M. and Lilja, M. (2014) 'Understanding Hybrid Democracy in Cambodia: The Nexus Between Liberal Democracy, the State, Civil Society, and a Politics of Presence', Asian Politics \& Policy, 6 (1), 5-24. 
Cai, Y. (2010) Collective resistance in China: Why popular protests succeed or fail, Standford, California: Stanford University Press.

CDC (Council for Development of Cambodia). (2010) Cambodian Investment Board: Projects by Sector Approved, Phnom Penh: Councils for Development of Cambodia.

Cress, D.M. and Snow, D.A. (2000) 'The outcomes of homeless mobilization: The influence of organization, disruption, political mediation, and framing', American Journal of Sociology, 105 (4), 1063-1104.

Dalton, R.J., Kuechler, M. and Burklin, W. (1990) 'The Challenge of New Movements', in R.J. Dalton and M. Kuechler, Challenging the political order: New social and political movements in western democracies, New York: Oxford University Press, 3-20.

Gamson, W. A. (1990) The strategy of social protest, Belmont, Calif: Wadsworth Publication.

George, A.L. and Bennett, A. (2005) Case studies and theory development in the social sciences, Massachusett: MIT Press.

Giugni, M. (1998) 'Was it worth the effort? The outcomes and consequences of social movements', Annual Review of Sociology, 24, 371-93.

Goldstone, J.A and Tilly, C. (2001) 'Threat (and opportunity): Popular action and state response in the dynamics of contentious action', in R. Aminzade, J.A. Goldstone, D. McAdam and E. Perry (eds), Silence and voice in the study of contentious politics, Cambridge, New York: Cambridge University Press, 179-94.

Gusfield, J.R. (1984) The culture of public problems: Drinking-driving and the symbolic order, Chicago: University of Chicago Press.

Heder, S. (1995) 'Cambodia Democratic Transition to neoauthoritarianism', Current History, 596, 425-429.

Hughes, C. (2003) Political Economy of the Cambodian Transition, Routledge: London.

Hutter, M.B. and O'Mahony, J. (2004) The Role of Civil Society Organizations in Regulating Business, Centre for Analysis of Risk and Regulation, London: London School of Economics and Political Sciences.

Jordan, L. and Van Tuijl, P. (2000) 'Political responsibility in transnational NGO advocacy', World Development, 28 (12), 2051-2065.

Keck, M.E. and Sikkink, K. (1998) Activists beyond borders: Advocacy networks in international politics, USA: Cornell University Press.

Keck, M.E and Sikkink, K. (1999) Transnational advocacy networks in international and regional politics', International Social Science Journal, 51(159), 89-101.

King, B.G. (2008) 'A political mediation model of corporate response to social movement activism', Administrative Science Quarterly, 53 (3), 395-421.

King, B.G. and Soule, S.A. (2007) 'Social movements as extra-institutional entrepreneurs: The effect of protests on stock price returns', Administrative Science Quarterly, 52 (3), 413-42.

Lilja, M. (2010) 'Discourses of hybrid democracy: The case of Cambodia', Asian Journal of Political Science, 18 (3), 289-309.

McAdam, D. (1983) 'Tactical innovation and the pace of insurgency', American Sociological Review, 48 (6), 735-54.

McAdam, D. and Tarrow, S. (2000) 'Nonviolence as contentious interaction', PS: Political Science and Politics, 33 (2), 149-54.

McAdam, D., Tarrow, S.G. and Tilly, C. (2001) Dynamics of contention, Cambridge studies in contentious politics, Cambridge, New York: Cambridge University Press.

Macdonald, K. (2014) The Politics of Global Supply Chains: Power and Governance Beyond the State, UK, USA: Polity Press. 
McIntosh, M. and Thomas, R. (2002) Corporate Citizenship and the Evolving Relationship between non-Governmental organizations and corporations, UK: British-North American Committee.

Meierotto, L. (2009) 'The uneven geographies of transnational advocacy: The case of the Talo Dam', Journal of Environmental Management, 90, 279-285.

Miller, T. (2011) 'Bitter Tast of Sugar Trading, the Phnom Penh Post, May 2011', viewed Feb 28, 2014, <http://www.phnompenhpost.com/national/bitter-taste-sugartrading\%3E.>

Milne, S., and Mahanty, S. (2015) 'The Political Ecology of Cambodia's Transformation', in S. Milne and S. Mahanty (eds.), Conservation and Development in Cambodia: Exploring Frontiers of Change in Nature, State and Society, New York: Routledge, 127.

NGO Forum. (2011) Statistical Analysis on Land Disputes Occurring in Cambodia 2010. Phnom Penh: NGOs Forum.

Nugroho, Y. (2011) 'Opening the black box: The adoption of innovations in the voluntary sector-The case of Indonesian civil society organisations', Research Policy, 40 (5), 761-77.

O'Brien, K.J and Li, L. (2006) Rightful resistance in rural China, Cambridge studies in contentious politics, Cambridge, New York: Cambridge University Press.

Pellechi, G. (2012) 'Koh Kong King Bowed out of 'Blood Sugar' Fairm', The Phnom Penh Post, August 01, 2012, viewed February 28, 2014.

Royal Decree (2001) Land Law, Phnom Penh: RGC.

RGC (Royal Government of Cambodia) (1999) Sub-decree on Environmental Impact Assessment, Phnom Penh: Royal Governnment of Cambodia.

RGC (2005) Sub-decree on Economic Land Concessions, Phnom Penh: Royal Governnment of Cambodia.

RGC (2012) Order 01BB on the Measures Strengthening and Increasing the Effectiveness of the Management of Economic Land Concessions, Phnom Penh: RGC.

Schoenberger, L. (2015) 'Winning back land in Cambodia: community work to navigate state land titling campaigns and large land deals'. Paper presented at Chiang Mai University, Thailand.

Scott, J. C. (1972) 'The erosion of patron-client bonds and social change in rural Southeast Asia, The Journal of Asian Studies, 32(1), 5-37.

Shawki, N. (2011) 'Organizational structure and strength and transnational campaign outcomes: a comparison of two transnational advocacy networks', Global Networks, 11 (1), 97-117.

Smith, J. (2004) 'Transnational processes and movements', in D. A Snow, S.A Soule, and H. Kriesi (eds.), The Blackwell companion to social movements, USA, UK, Australia: Blackwell Publishing Ltd, 311-337.

Sokphea, Y. (2015) Contention and Corporate Sustainability Practices in the Cambodian Agricultural Sector. Hong Kong SAR: Southeast Asia Research Centre, City University of Hong Kong.

(2016) 'Movement of Indigenous Communities Targeting An Agro-industrial Investment in Northeastern Cambodia', Asian Journal of Social Science, 44(1-2), 188214.

(Forthcoming) 'Popular Resistance in Cambodia: The rationale behind Government response', Asian Politics \& Policy.

Soule, S.A. (2009) Contention and corporate social responsibility, UK: Cambridge University Press. 
(2012) 'Social Movements and Markets, Industries, and Firms', Organization Studies, 33 (12), 1715-33.

Steedly, H.R. and Foley, J.W. (1979) 'The success of protest groups: Multivariate analyses', Social Science Research, 8 (1), 1-15.

Touch, S. and Neef, A. (2015) 'Resistance to Land Grabbing and Displacement in Rural Cambodia'. Paper presented at Chiang Mai University, Thailand.

Un, K. (2009) 'China's Foreign Investment and Assistance: Implications for Cambodia' Development and Democratization', Peace and Conflict Studies, 16 (2), 65-81.

(2011) 'Cambodia: Moving away from democracy?' International Political Science Review, 32 (5), 546-562.

(2013) 'Cambodia in 2012: Towards Developmental Authoritarianism? Southeast Asian Affairs', 2013 (1), 71-86.

Un, K. and So, S. (2011) 'Land Rights in Cambodia: How Neopatrimonial Politics Restricts Land Policy Reform', Pacific Affair, 84 (2), 289-308.

Van Dyke, N., Soule, S.A. and Taylor, V.A. (2005) 'The targets of social movements: Beyond a focus on the state', Research in Social Movements, Conflicts and Change, 25, 27-51.

\section{Appendix 1: List of Participants}

\begin{tabular}{|l|l|r|}
\hline Codes & Position & Date of Interview \\
\hline P01 & Village Chief 1 & 03 Nov 2013 \\
\hline P02 & Executive Director-NGO & 06 Dec 2013 \\
\hline P03 & Former Commune Chief & 04 Nov 2013 \\
\hline P04 & Community Activist 1 & 01 Nov 2013 \\
\hline P05 & Deputy Provincial Governor & 15 Dec 2013 \\
\hline P06 & Lawyer-NGO & 20 Dec 2013 \\
\hline P07 & Director-Environment & 16 Dec 2013 \\
\hline P08 & Deputy Director-Land Management & 02 Jan 2013 \\
\hline P09 & Village Chief 2 & 01 Nov 2013 \\
\hline P10 & Community Activist 2 & 02 Nov 2013 \\
\hline P11 & Village Chief 3 & 04 Nov 2013 \\
\hline P12 & Community Activist 3 & 01 Nov 2013 \\
\hline P13 & Executive Officer- Company & 13 Jan 2014 \\
\hline P14 & CSR Manager-Company & 13 Jan 2014 \\
\hline P15 & Independent Researcher & 26 Nov 2013 \\
\hline P16 & University Lecturer & 02 Jan 2014 \\
\hline P17 & Provincial Manager-NGO & 16 Dec 2013 \\
\hline P18 & Provincial Manager-NGO & 04 Dec 2013 \\
\hline P19 & President-NGO & 26 Dec 2013 \\
\hline P20 & EU Cambodia & 15 Jan 2014 \\
\hline P21 & ELC Secretariat Officer & 03 Dec 2013 \\
\hline P22 & Member of Parliament & 18 Dec 2013 \\
\hline FGD1 & Village A (10 villagers) & 02 Nov 2013 \\
\hline FGD2 & Village B (10 villagers) & 02 Nov 2013 \\
\hline & & \\
\hline
\end{tabular}

